\title{
Immunogenicity of HLA-A1-restricted peptides derived from S100A4 (metastasin 1) in melanoma patients
}

\author{
Valeska Hofmeister-Mueller • Claudia S. Vetter-Kauczok • Ramona Ullrich • \\ Katharina Meder · Eugene Lukanidin · Eva-Bettina Broecker • Per thor Straten • \\ Mads Hald Andersen · David Schrama · Juergen C. Becker
}

Received: 14 November 2007 / Accepted: 4 December 2008 / Published online: 13 January 2009

(C) The Author(s) 2008. This article is published with open access at Springerlink.com

\begin{abstract}
S100A4 (metastasin 1) belongs to the S100 family of $\mathrm{Ca}^{2+}$ binding proteins. While not present in most differentiated adult tissues, S100A4 is upregulated in the micromilieu of tumors. It is primarily expressed by tumorassociated macrophages, fibroblasts, and tumor endothelial cells. Due to its strong induction in tumors S100A4 is a promising target for cancer immunotherapy. By reverse immunology, using epitope prediction programs, we identified 3 HLA-A1-restricted peptide epitopes (S100A4 A1-1, A1-2, and A1-3) which are subject to human $\mathrm{T}$ cell responses as detected in peripheral blood of melanoma patients by means of IFN- $\gamma$ ELISPOT and cytotoxicity assays. In addition, IFN- $\gamma$ responses to S100A4 A1-2 can not only be induced by stimulation of T cells with peptideloaded DC but also by stimulation with S100A4 proteinloaded DC, indicating that this epitope is indeed generated by processing of the endogenously expressed protein. In addition, S100A4 A1-2 reactive $\mathrm{T}$ cells demonstrate lysis of HLA-A $1^{+}$fibroblasts in comparison to HLA-A $1^{-}$fibroblasts. In summary, this HLA-A1-restricted peptide epitope
\end{abstract}

\footnotetext{
V. Hofmeister-Mueller $(\bowtie) \cdot$ C. S. Vetter-Kauczok $\cdot$ R. Ullrich .

K. Meder · E.-B. Broecker - D. Schrama - J. C. Becker

Department of Dermatology, Venerology and Allergology,

University of Wuerzburg, Josef-Schneider-Str. 2,

97080 Würzburg, Germany

e-mail: Hofmeister_V@ @linik.uni-wuerzburg.de

E. Lukanidin

Institute of Cancer Biology, Danish Cancer Society,

Copenhagen, Denmark

P. thor Straten - M. H. Andersen

Center for Cancer Immunotherapy (CCIT),

Department of Hematology, Herlev University Hospital,

2730 Herlev, Denmark
}

is a candidate for immunotherapeutical approaches targeting S100A4-expressing cells in the tumor stroma.

Keywords CTL $\cdot$ HLA-A1 epitope $\cdot$ Melanoma .

Metastasin $1 \cdot$ S100A4 $\cdot$ Tumor stroma

\section{Introduction}

S100A4, also referred to as metastasin 1 (mts1), fibroblastspecific protein 1 (FSP1), placental calcium-binding protein, CAPL, calvasculin, p9Ka, pEL-98, 18A2, or 42A belongs to the family of EF-hand calcium-binding proteins. S100A4 has both intracellular and extracellular functions. By binding to different target molecules S100A4 influences cell motility, invasion, adhesion, proliferation, apoptosis, remodeling of the extracellular matrix, and angiogenesis $[15,41]$. S100A4 expression is enhanced under several pathological conditions including cancer, where it might be expressed in and released from tumor cells, tumor stroma cells or both [8, 48, 49]. Indeed, S100A4 expression was demonstrated in many cell types participating in formation of the tumor stroma, e.g., cancer-associated fibroblasts, tumor endothelial cells, and tumor-associated macrophages. Notably, an extensive study in breast cancer describes preferential expression of S100A4 in macrophages and fibroblasts [8]. All these stroma cells contribute to the development and progression of cancer by secretion of growth and angiogenic factors or extracellular matrix degrading enzymes leading to enhanced tumor cell proliferation, invasion, angiogenesis, and finally metastasis and in consequence are potential anti-cancer therapeutical targets $[20,21,31]$. S100A4 itself has been implicated in disease development and progression, as it promotes the oncogenic phenotype of tumor cells. Its expression has been described 
for a variety of cancer entities, e.g., carcinoma of the breast [12, 22, 30, 37, 46, 54], ovary [25], thyroid [23, 36, 57], esophagus [38], bladder [1, 11], gallbladder [9], colon [53], colorectum [10, 19], pancreas [2, 40, 45] and prostate [17], gastric cancers [14, 26, 55], lung [27, 34], and brain cancers $[44,52]$. S100A4 expression has also been described in primary and metastatic melanoma [3, 32, 39]. Elevated S100A4 levels are associated with a more aggressive phenotype and a poor prognosis $[11,18,26,36]$. Due to its involvement in disease development and progression and its broad expression in the tumor microenvironment, S100A appears as an attractive target for cancer therapy that should allow the destruction of the tumor directly by targeting the cancer cells themselves and indirectly by destroying the supporting tumor stroma cells. Indeed, the destruction of the tumor stroma may be essential to eradicate tumors [56].

Up to date, approaches for down-regulation of S100A4 expression by ribozymes [33] or RNA interference [51, 52] have demonstrated the feasibility of S100A4-directed antitumor therapies. For example, the reduction of its expression in a murine model of thyroid carcinoma was accompanied by enhanced sensitivity to chemotherapy [51]. To analyse if S100A4 may be a therapeutic target for cancer immunotherapy, we applied reverse immunology to identify S100A4-derived T cell epitopes and demonstrated their immunogenicity ex vivo as well as the occurrence of spontaneous immune responses against these in melanoma patients.

\section{Materials and methods}

Cells and cell lines

The HLA-A1 ${ }^{+}$lymphoblastoid cell line BM36.1 and the melanoma cell lines MelJuso, Mel2a, and Mel888 were cultured in RPMI 1640/10\% FCS supplemented with $100 \mathrm{U}$ penicillin/ml and $100 \mu \mathrm{g}$ streptomycin/ml.

Human skin fibroblasts were isolated by incubation of normal skin tissue pieces obtained from the margins after resection of nevi or cancerous lesions in $0.25 \%$ collagenase (Collagenase D, Boehringer Mannheim, Mannheim, Germany) and $0.1 \mathrm{mg} / \mathrm{ml}$ DNAse. The resulting suspension was filtered through a fine mesh. Obtained cells were maintained in RPMI 1640 supplemented with 10\% FCS.

After informed consent PBL were collected from HLA$\mathrm{A} 1^{+}$patients $(n=16)$ with advanced malignant melanoma. PBL were isolated using Lymphoprep separation (AxisShield PoC AS, Oslo, Norway) according to the manufacturer's instructions and used directly or after cryopreservation. PBL were cultured in RPMI 1640/10\% human AB serum. $\mathrm{CD}^{+} \mathrm{T}$ cells were negatively selected using the $\mathrm{CD} 8^{+} \mathrm{T}$
Cell Isolation Kit II (Miltenyi Biotec GmbH, Bergisch Gladbach, Germany) according to the manufacturer's recommendations.

Dendritic cells were generated from PBL by adherence on culture dishes at $37^{\circ} \mathrm{C}$ for $60 \mathrm{~min}$ in RPMI 1640 enriched with $10 \%$ human $\mathrm{AB}$ serum. Adherent monocytes were cultured in RPMI 1640 supplemented with $10 \%$ human $\mathrm{AB}$ serum in the presence of IL-4 $(1,000 \mathrm{U} / \mathrm{ml})$ and GM-CSF $(800 \mathrm{U} / \mathrm{ml})$ for 6 days. DCs were matured by addition of IL1 $\beta(2 \mathrm{ng} / \mathrm{ml})$, IL-6 $(1,000 \mathrm{U} / \mathrm{ml})$, TNF $\alpha$ $(10 \mathrm{ng} / \mathrm{ml})$, and PGE2 $(1 \mu \mathrm{g} / \mathrm{ml})$. The next day the resulting mature DC were pulsed with $10 \mu \mathrm{M}$ peptide and $3 \mu \mathrm{g} \beta 2$ microglobulin $/ \mathrm{ml}$ overnight at $37^{\circ} \mathrm{C}$. For loading of DC with $\mathrm{S} 100 \mathrm{~A} 4$ protein $1 \times 10^{6} \mathrm{immature} \mathrm{DC} / \mathrm{ml}$ were incubated with $50 \mu \mathrm{g}$ protein $/ \mathrm{ml}$ overnight before adding the maturing cocktail.

Immunohistochemical staining

After pre-treatment with $0.1 \%$ pronase (Roche Diagnostics $\mathrm{GmbH}$, Mannheim, Germany) for $20 \mathrm{~min}$ at $37^{\circ} \mathrm{C}$ and proteinase K (Dako, Hamburg, Germany) for $10 \mathrm{~min}$ at room temperature, respectively, paraffin sections of normal skin, nevi, and melanoma were stained with S100A4-specific rabbit antiserum or anti CD68 clone PG-M1 (Dako) and the appropriate DakoCytomation Envison ${ }^{+}$Systems (Dako) followed by the Vector Nova red system (Vector Laboratories, Burlingame, USA) according to the manufacturer's instructions. As negative control sections were stained with normal rabbit antiserum or without primary antibody, respectively.

\section{S100A4 nonamer peptides}

HLA-A1-restricted nonamer peptides derived from the fulllength human S100A4 protein were selected using both SYFPEITHI [43] and BIMAS [42] peptide binding algorithms freely available via the internet (http://www.syfpeithi.de/ and http://bimas.cit.nih.gov/molbio/hla_bind/). The peptides were synthesized by GenScript Corporation (Piscataway, New Jersey, USA). HLA-A1-restricted peptides derived from influenza nucleoprotein (NP) peptide 44-52 (CTELKLSDY) [13] were used as controls.

\section{ELISPOT assays}

The human IFN- $\gamma$ ELISPOT assay was used to quantify peptide epitope-specific IFN- $\gamma$-releasing effector cells as described previously [5]. Briefly, nitrocellulose-bottomed 96-well plates (MultiScreen MAIP N45, Millipore GmbH, Schwalbach, Germany) were activated with $35 \%$ ethanol, washed with PBS, and coated with anti-IFN- $\gamma$ Ab (1-D1K, Mabtech, Hamburg, Germany). The wells were washed and 
blocked by X-vivo medium (Cambrex Biosciences, Verviers, Belgium) before adding $1 \times 10^{4}$ stimulator BM36.1 cells loaded with or without $10 \mu \mathrm{M}$ peptide and $3 \times 10^{5}$, $1 \times 10^{5}$, or $3 \times 10^{4}$ effector cells. To minimize background in samples stimulated with DC preincubated with S100A4 protein or peptides, only $1 \times 10^{5}, 3 \times 10^{4}$, and $1 \times 10^{4}$ effector cells were used. After incubation overnight the wells were washed with PBS followed by addition of biotinylated secondary Ab (7-B6-1-Biotin, Mabtech, diluted in PBS/1\% BSA). The plates were incubated for $2 \mathrm{~h}$, washed, and streptavidin-enzyme conjugate (Streptavidin-ALP-PQ, Mabtech, diluted in PBS/1\% BSA) was added. Incubation at room temperature for $1 \mathrm{~h}$ was followed by washing with wash buffer and substrate buffer $(0.1 \mathrm{M} \mathrm{NaCl}, 50 \mathrm{mM}$ $\mathrm{MgCl}_{2}, 0.1 \mathrm{M}$ Tris-HCl, $\mathrm{pH}$ 9.5), and addition of enzyme substrate NBT/BCIP (Mabtech). The reaction was stopped by washing with tap water upon the appearance of dark purple spots. Spots were counted using the ImmunoSpot Series 2.0 Analyzer (CTL Cellular Technology Ltd., Schwäbisch Gmünd, Germany). The peptide-specific CTL frequency was calculated from the numbers of spot-forming cells. All assays were performed at least in duplicates. To extend the sensitivity of the ELISPOT assay, PBL were stimulated once in vitro before analysis. At day $0, \mathrm{PBL}$ were plated in a cell concentration of $1 \times 10^{6} / \mathrm{ml}$ in 6-well plates (Greiner $\mathrm{GmbH}$, Frickenhausen, Germany) in X-vivo medium (Cambrex) supplemented with $10 \%$ heat inactivated human $\mathrm{AB}$ serum in the presence of $10 \mu \mathrm{M}$ peptide (GeneScript Corporation). Alternatively, $1 \times 10^{5}$ irradiated (50 Gy) $\mathrm{DC} / \mathrm{ml}$ loaded with $\mathrm{S} 100 \mathrm{~A} 4$ protein or peptide were used for stimulation of $1 \times 10^{6} \mathrm{PBL} / \mathrm{ml}$ in the presence of $40 \mathrm{U}$ IL-2/ml (Proleukin, Chiron GmbH, Munich, Germany). IL2 was added every 3-4 days to the culture. The cultured cells were tested for reactivity in ELISPOT on day 7.

\section{Cytotoxicity assay}

For the microcytotoxicity assay, $2 \times 10^{2}$ target cells/well were plated in Terasaki plates (Nunc, Wiesbaden, Germany) for $24 \mathrm{~h}$. After $24 \mathrm{~h}$, the in vitro prestimulated lymphocytes were added at effector:target ratios of 30:1 and 10:1 in a final volume of $10 \mu \mathrm{l}$ [7]. After overnight incubation, the plates were washed, fixed with $-20^{\circ} \mathrm{C}$ cold methanol, and stained with Giemsa-Solution (Merck, Darmstadt, Germany). All stained target cells were counted and the percent of lysis was calculated. As negative control target cells only, without adding effector cells, were used. In addition, specific lysis of fibroblasts or Mel2a was analysed in a 4 hour standard chromium release assay. Mel2a targets were preincubated with or without $10 \mu \mathrm{M}$ peptide, $20 \mu \mathrm{g} / \mathrm{ml} \mathrm{W} 6 / 32$ antibody (Dako, Hamburg, Germany), or IgG2a isotype control antibody (Dianova, Hamburg, Germany). Cold targets were prein- cubated with $10 \mu \mathrm{M}$ S100A4 A1-2 or irrelevant peptide derived from influenza NP 44-52.

Sequence similarity search

A search for proteins containing the identified S100A4 peptides was done using the protein blast tool available at http://www.ncbi.nlm.nih.gov.

Statistical analysis

Statistical analysis was performed using GraphPad Prism version 4.03 for Windows (GraphPad Software, San Diego California USA, www.graphpad.com).

\section{Results}

S100A4 is upregulated in the tumor micromilieu

S100A4 upregulation in tumor and stroma cells has been demonstrated previously in a variety of cancers. Accordingly, immunohistochemical staining of normal skin and melanoma demonstrates that in situ expression of S100A4 in normal skin is absent or restricted to macrophages (Fig. 1a, e). Although in melanoma the extend of expression varied between patients (Fig. $1 \mathrm{~b}, \mathrm{c}$ ), in addition to macrophages, cancer-associated fibroblasts, tumor endothelial cells, and melanoma cells themselves are S100A4 ${ }^{+}$ (Fig. 1). No positive cells were detected in control stainings with normal rabbit serum. Notably, we also detected S100A4 protein expression in benign nevi (data not shown).

Spontaneous IFN- $\gamma$ responses to HLA-A1-restricted S100A4-derived peptide epitopes

The complete amino acid sequence of the human S100A4 protein consisting of 101 amino acids was searched for putative HLA class I binding peptides using the epitope prediction programs BIMAS [42] and SYFPEITHI [43]. Epitopes with SYFPEITHI scores $>20$ were found for HLA-A1, -A3, and -B8, whereas no high affinity peptides restricted to the HLA class I antigens HLA-A2, -B7, or -B27 were predicted. The highest score was reached for the HLA-A1-restricted peptides. Thus, we focussed on HLAA1-restricted S100A4 epitopes in the further studies. In addition, the HLA-A1 allele is frequently expressed in the Caucasian population (www.allelefrequencies.net) [35]. To this end, three HLA-A1-restricted nonamer peptides (S100A4 A1-1, S100A4 A1-2, and S100A4 A1-3) with scores $>20$ for SYFPEITHI were synthesized (Table 1, Fig. 2a). We tested for spontaneous CTL responses to these 

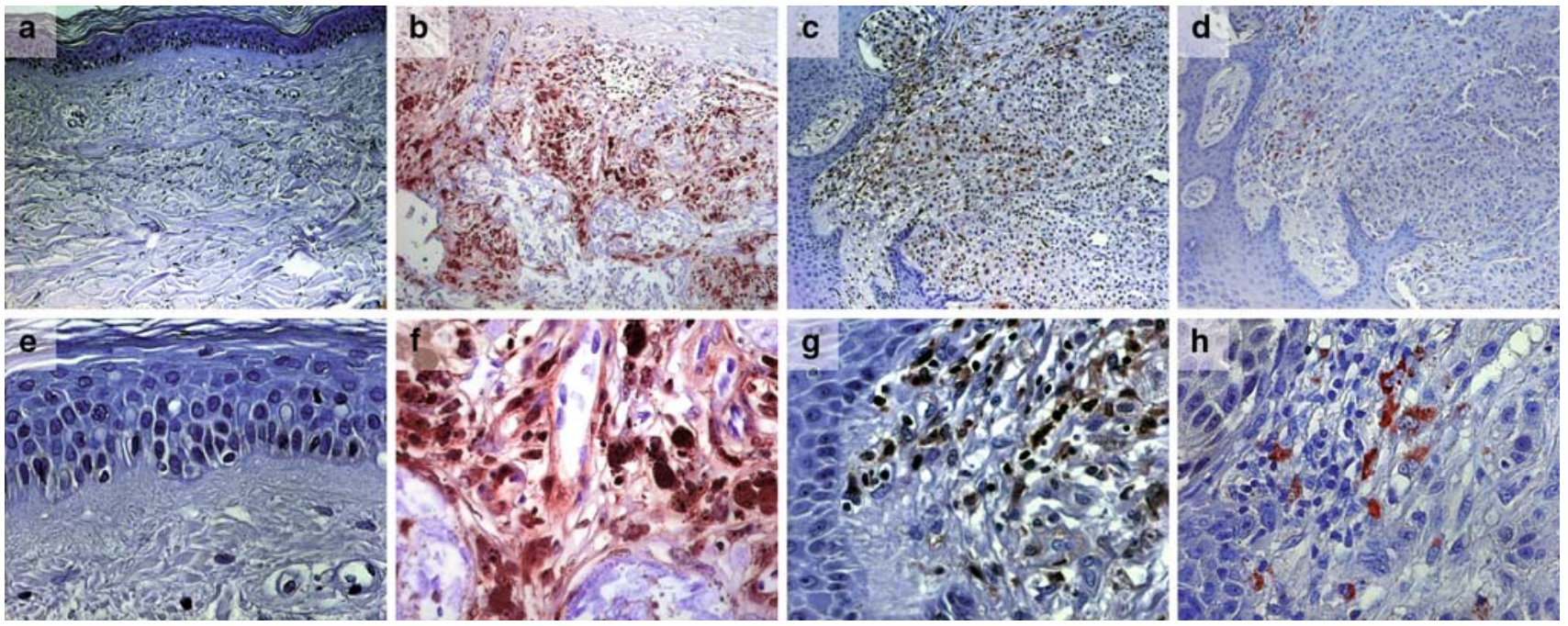

Fig. 1 S100A4 expression in the skin. Sections of normal skin $(\mathbf{a}, \mathbf{e})$ and primary melanoma $(\mathbf{b}-\mathbf{d}, \mathbf{f}-\mathbf{h})$ were stained with anti-S100A4 antiserum $(\mathbf{a}-\mathbf{c}, \mathbf{e}-\mathbf{g})$ or anti CD68 $(\mathbf{d}, \mathbf{h}) . \times 10(\mathbf{a}-\mathbf{d})$ and $\times 40(\mathbf{e}-\mathbf{h})$

Table 1 Position, amino acid sequence, and peptide binding prediction of HLA-A1-restricted S100A4 peptides

\begin{tabular}{llll}
\hline Name & Position & Sequence & SYFPEITHI score $^{a}$ \\
\hline S100A4 A1-1 & $11-19$ & VMVSTFHKY & 21 \\
S100A4 A1-2 & $31-39$ & KSELKELLT & 22 \\
S100A4 A1-3 & $67-75$ & DNEVDFQEY & 28 \\
\hline
\end{tabular}

${ }^{a}$ The higher the score the higher the affinity predicted

S100A4 epitopes ex vivo. Therefore, we scrutinized PBL from HLA-A $1^{+}$melanoma patients by IFN- $\gamma$ ELISPOT. This analysis revealed, that in several patients IFN- $\gamma$ responses to the three HLA-A1-restricted peptides were indeed detected (Fig. 2b, c).

Peptide- versus protein-induced $\mathrm{T}$ cell responses

To further evaluate the immunogenicity of both S100A4 and the S100A4-derived peptides, we stimulated lymphocytes from HLA-A $1^{+}$donors in vitro with DC which where either given the possibility to process the whole protein or pulsed with the peptides. The response was measured by IFN- $\gamma$ release ELISPOT assay to either protein or peptides. This analysis revealed that, in contrast to the epitopes S100A4 A1-1 and A1-3, IFN- $\gamma$ responses to the peptide S100A4 A1-2 were not only induced by the respective peptides but also after in vitro stimulation using DC which processed the whole protein (Fig. 2d). The lack of IFN- $\gamma$ response to the S100A4 A1-1 and A1-3 peptides after stimulation with S100A4 protein-loaded DC indicates that in this case no unspecific or $\mathrm{CD} 4^{+} \mathrm{T}$ cell responses were induced. This indicates that only the S100A4 A1-2 epitope is cross-presented and indeed generated by natural process- ing of the antigen, whereas the epitopes A1-1 and A1-3 albeit binding to HLA-A1 are not. Furthermore, after prestimulation with DC which processed S100A4 protein the IFN- $\gamma$ release response to the complete S100A4 protein was significantly higher than in the response to the S100A4 A1-2 peptide indicating that other epitopes than the S100A4 A1-2 contribute to the anti S100A4 immune reaction (Fig. 2e). Although the majority of the additional immune response can likely be attributed to $\mathrm{CD} 4^{+} \mathrm{T}$ cells, it is also feasible that other MHC class I epitopes are cross-presented.

\section{Cytotoxic activity of S100A4-specific T cells}

The lytic capacity of S100A4-reactive CTL was tested in cytotoxicity assays. To this end, lymphocytes were stimulated with DC pulsed with S100A4 peptides A1-2, A1-3, or influenza NP peptide. Subsequently, lysis of peptide-loaded HLA-A $1^{+}$melanoma cell line MelJuso was evaluated (Fig. 3a). Notably, the target cells were either used directly or after pulse with the indicated peptides. All peptideloaded target cells were similarly lysed by the activated lymphocytes. However, only lymphocytes stimulated with the naturally processed S100A4 peptide, i.e., S100A4 A1-2, were able to lyse the $\mathrm{S} 100 \mathrm{~A} 4^{+}$target cell without the additional peptide pulse; thus, confirming the earlier observation that only the S100 A4 A1-2 peptide epitope is suitable for S100A4 targeted immunotherapy. In order to test if S100A4 peptide-induced CTL would also recognize cancer-associated fibroblasts, we performed cytotoxicity assays against in vitro stimulated fibroblasts expressing S100A4. Confirming the prior analyses S100A4 A1-2 stimulated PBL lysed fibroblast much more effectively than S100A4 A1-1 and A1-3 stimulated PBL (Fig. 3b). Besides, lysis of HLA-A1 ${ }^{+}$ fibroblasts by S100A4 A1-2-stimulated PBL was clearly 
a
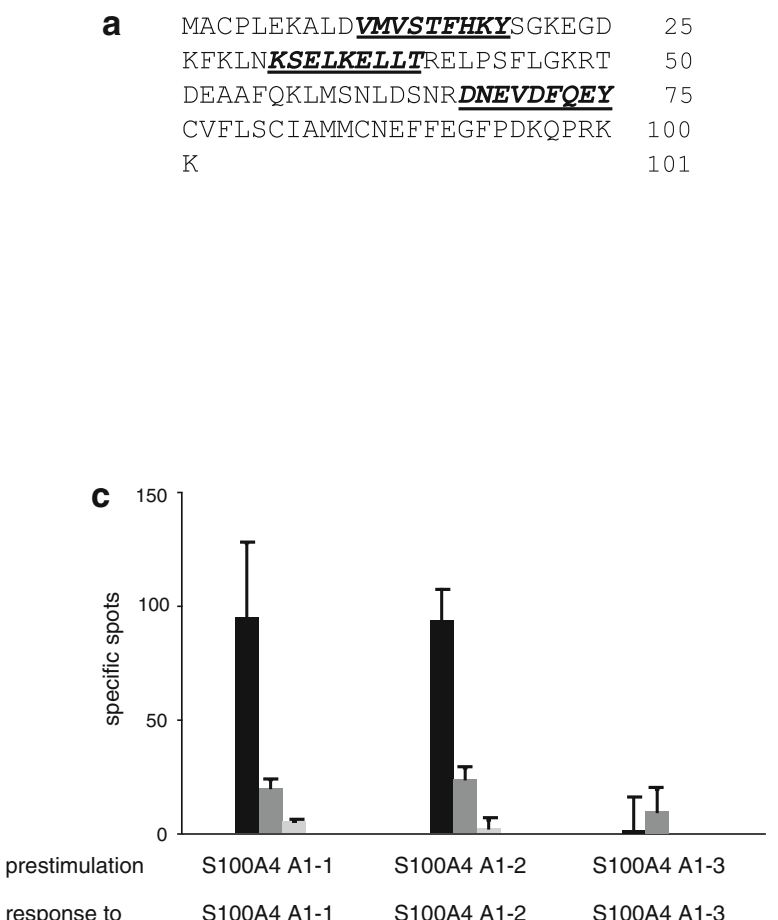
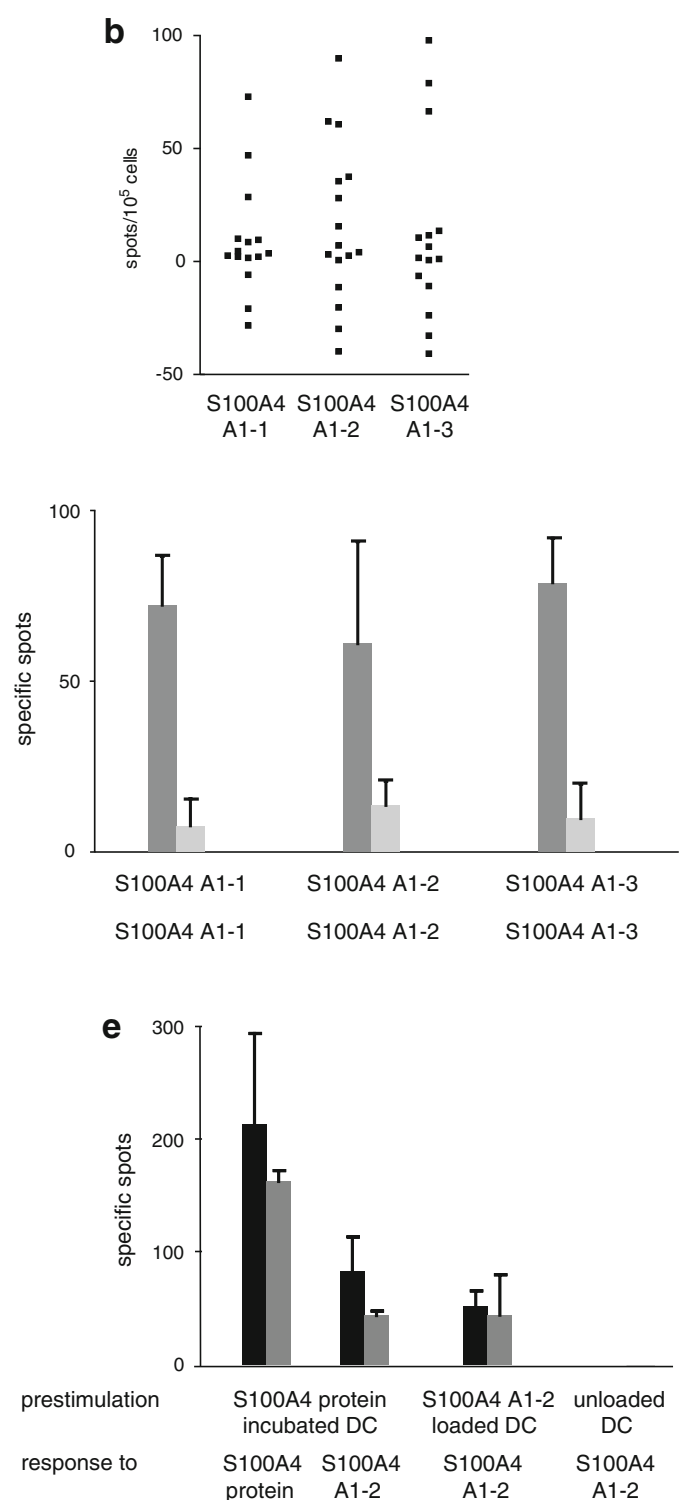

spots $/ 3 \times 10^{5}$ cells (black columns), $1 \times 10^{5}$ cells (dark gray columns), and $3 \times 10^{4}$ cells (light gray columns). $\mathbf{d} 1 \times 10^{4} \mathrm{PBL}$ of a melanoma patient prestimulated with DC loaded with S100A4 peptides A1-1, A1-2, or A1-3 (black columns) or with S100A4 protein (gray columns) were tested for their reactivity to S100A4 peptide-loaded DC in IFN- $\gamma$ ELISPOT. e $1 \times 10^{5}$ (black columns) and $3 \times 10^{4}$ (gray columns) PBL of a melanoma patient were prestimulated with empty DC, DC incubated with S100A4 protein or DC loaded with the S100A4 A12 epitope. The IFN- $\gamma$ response to the $\mathrm{S} 100 \mathrm{~A} 4$ protein and A1-2 epitope were analysed by ELISPOT

dependent cytotoxic activity (Fig. 3c). Furthermore, cold target inhibition experiments revealed that the $\mathrm{T}$ cells lysing the S100A4 expressing melanoma cells are the same that recognize the peptide-loaded target cells. Coincubation with the HLA-A1 ${ }^{+},{\mathrm{S} 100 A 4^{-}}^{-}$cell line Mel888 loaded with S100A4 A1-2 significantly reduced lysis of hot targets by S100A4 1-2 stimulated $\mathrm{CD}^{+}$cells; in contrast, coincubation with cold targets loaded with the irrelevant influenza NP peptide 44-52 did not impair specific lysis (Fig. 3d). 

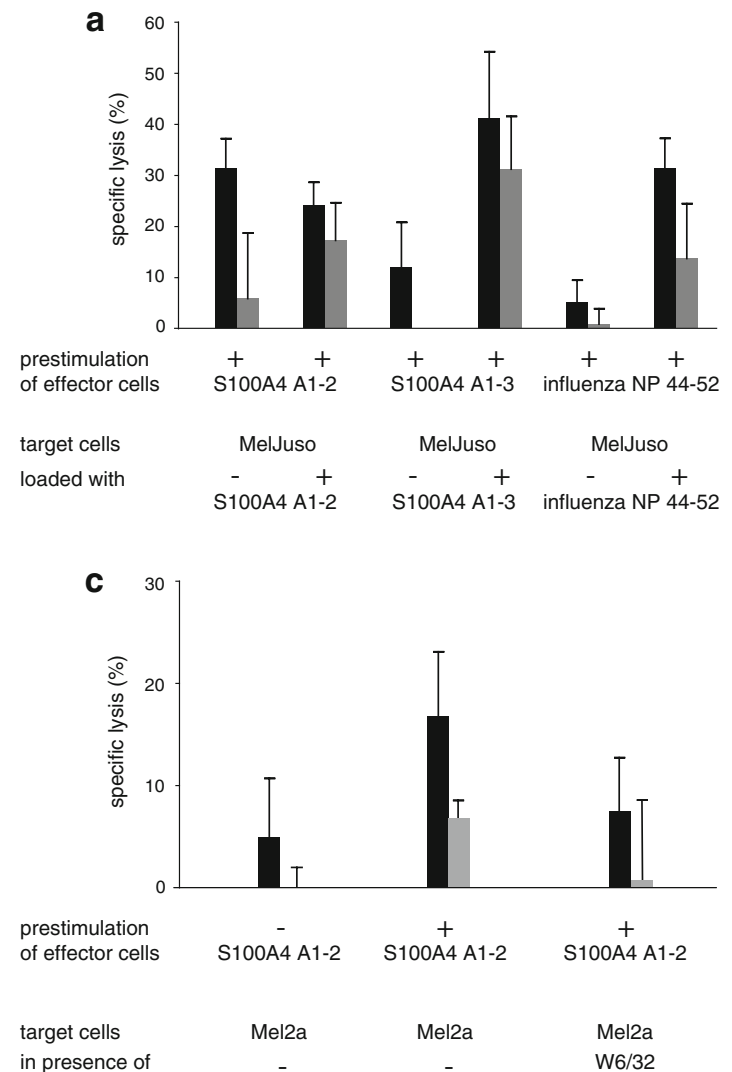

Fig. 3 S100A4 directed cytotoxic activity of PBL of melanoma patients. All effector cells were obtained from melanoma patients. a PBL were stimulated with DC incubated with S100A4 peptides A1-2, A1-3 or control peptide derived from influenza NP. Lysis of peptide pulsed cells of the HLA-A $1^{+}$melanoma cell line MelJuso was analysed by cytotoxicity assays in effector to target ratios of 30:1 (black columns), and 10:1 (gray columns). b S100A4 A1-1, A1-2 or A1-3 peptide incubated DC were used to stimulate PBL. Lysis of HLA-A $1^{+}$and HLA-A $1^{-}$fibroblasts was tested in cytotoxicity assays in effector to target ratios of 30:1. $\mathbf{c ~ C D} 8^{+} \mathrm{T}$ cell enriched PBL were stimulated with

Comparison of S100A4-derived peptides with S100 family members

To estimate the risk of S100A4 peptide-directed therapies, the amino acid sequences of S100A4 family members were searched for the S100A4 A1-1, A1-2, and A1-3 epitopes and Blast searches were done for each of the identified S100A4 peptides. Apart from S100A4, no identical hit appeared for S100A4 A1-1 and only one other exact match, i.e., leukemia multidrug resistance associated protein, turned up for S100A4 A1-2 and A1-3 (Fig. 4).

\section{Discussion}

Melanoma is an immunogenic tumor, known to induce spontaneous immune responses which may result in partial
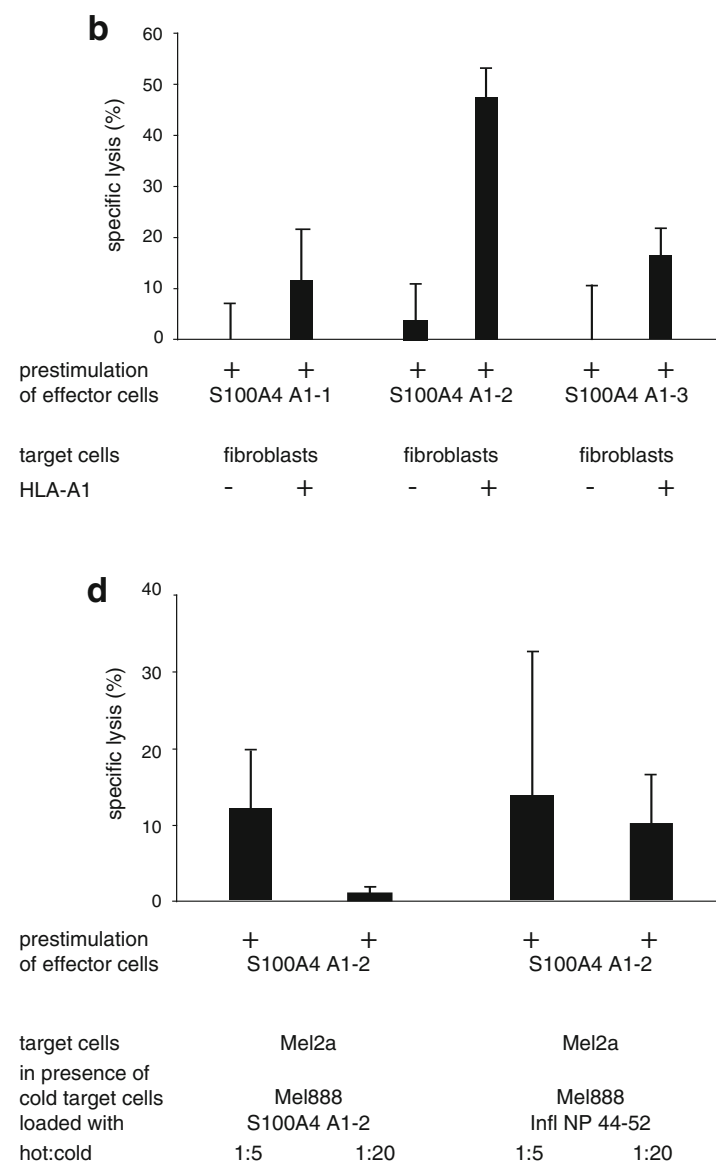

DC loaded or not with S100A4 A1-2 peptide. Lysis of the HLA-A1 ${ }^{+}$ $\mathrm{S} 100 \mathrm{~A}^{+}$melanoma cell line Mel2a, preincubated or not with $\mathrm{W} 6 / 32$, was analysed by cytotoxicity assay in effector to target ratios of $5: 1$ (black columns) and 2.5:1 (gray columns). d Lysis of Mel2a target cells by $\mathrm{CD}^{+} \mathrm{T}$ cells stimulated with $\mathrm{S} 100 \mathrm{~A} 4 \mathrm{~A} 1-2$ peptide-loaded DC was analysed in an effector to target ratio of 10:1 in a cold target inhibition assay. The S100A4 ${ }^{-}$, HLA-A1 ${ }^{+}$Mel888 cell line was incubated with the S100A4 1-2 epitope or an irrelevant control peptide and added as cold target in hot:cold ratios indicated

regressions of primary tumors. This observation has led to the development of several immune therapeutic approaches including tumor specific vaccination. We have selected S100A4 as immunological target molecule and verified its upregulation in the tumor micromilieu of melanoma (Fig. 1). In addition, a correlation between S100A4 protein expression in melanoma and aggressive phenotype, especially in early superficial spreading melanomas, has been described [3]. Notably, in the presented report we characterized a HLA-A1-restricted peptide epitope, S100A4 A12 , that is generated by processing of the complete S100A4 protein, demonstrated by reactivity to $\mathrm{S} 100 \mathrm{~A} 4$ proteinloaded DC, $\mathrm{HLA}-\mathrm{Al}^{+}$fibroblasts, and HLA-A $1^{+}$melanoma cells (Figs. 2 and 3). Interestingly, two other HLA-A1restricted peptide epitopes were predicted by the used computer algorithms and ex vivo immune responses to these epitopes were detected in peripheral blood of melanoma 


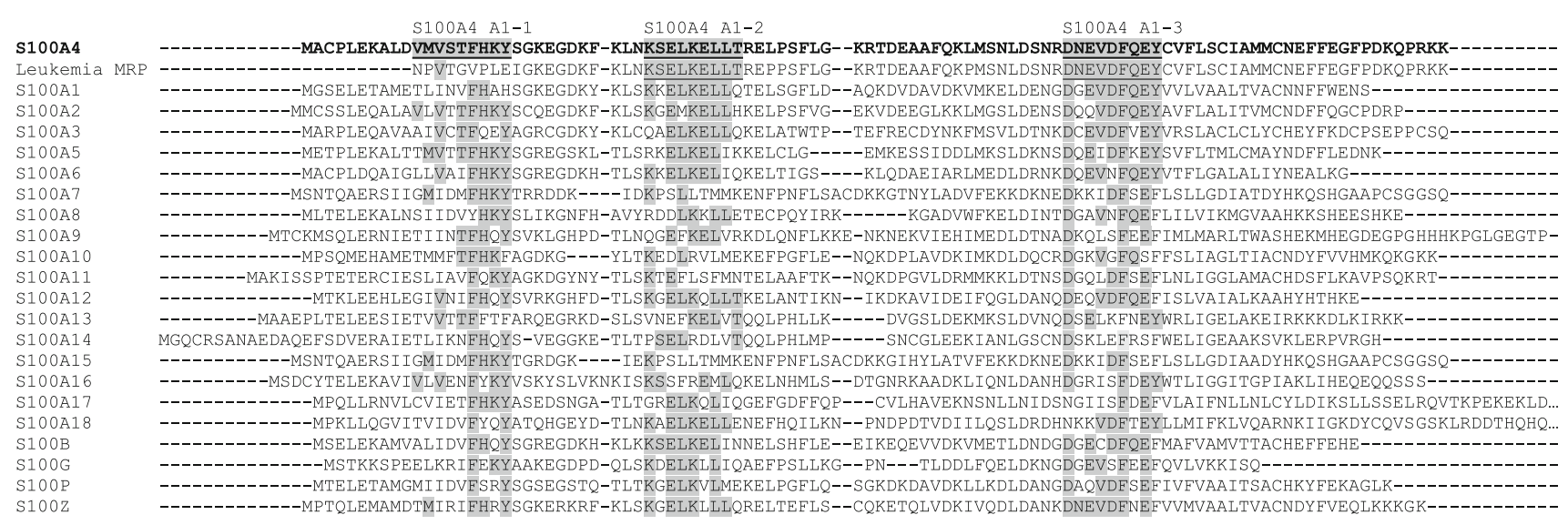

Fig. 4 Alignment of human S100 proteins. Comparison of S100A4 with other S100 family members to detect homologies within the epitopes S100A4 A1-1, A1-2, and A1-3 sequences; shaded squares indicate amino acid identity. MRP Multidrug resistance associated protein

patients, as well; however, when lymphocytes were stimulated with DC which processed the whole recombinant S100A4 protein only responses to one peptide, S100A4 A1-2, were induced. Vice versa only S100A4 A1-2 reactive $\mathrm{T}$ cells released IFN- $\gamma$ in response to $\mathrm{S} 100 \mathrm{~A} 4$ processing DC or killed target cells without these being pulsed with peptide. This observation illustrates the limitations of reverse immunology and confirms the need for confirmation assays demonstrating the presentation of identified epitopes by the desired target cells, e.g., S100A4 A1-2 on fibroblasts or melanoma cells.

The presented results suggest that $\mathrm{T}$ cell responses to S100A4 A1-2 can be induced by vaccination, e.g., allowing the development of an immune therapy with a low risk of inducing immune escape variants since S100A4 is expressed both in melanoma cells as well as in the genetically relatively stable tumor stroma cells, which promote tumor progression. However, it has to be noted that S100A4 expression is not completely restricted to tumor cells and tumor stroma cells. Although S100A4 expression has not been detected in most normal tissues, e.g., obtained from the breast, colon, thyroid, kidney, and pancreas, its expression has been described for lymphoid organs and white matter astrocytes $[16,28]$. Moreover, S100A4 is upregulated in injured tissues $[4,6,29,50]$. Another concern regarding side effects is cross targeting of other S100 family members. The $\mathrm{S} 100$ proteins are widely expressed and fulfill diverse functions [47]. The amino acid identity of S100A4 and other $\mathrm{S} 100$ proteins is up to $61 \%$ (S100A2). However, Blast search for the S100A4 A1-2 peptide resulted in one other identical hit apart from S100A4 only, i.e., leukemia multidrug resistance associated protein (Fig. 4). Leukemia multidrug resistance associated protein has once been described so far, in the leukemia cell line HL60 [24]. Although predictable side effects using S100A4 A1-2 due to cross reaction with other
S100A4 family members are low, possible adverse side effects of S100A4 targeting therapies have to be addressed in future studies.

In summary, S100A4 is an attractive target for anti-cancer therapy as its expression is elevated in the tumor micromilieu, both in tumor and tumor stroma cells. Hence, it is possible to develop strategies to simultaneously target different cell types contributing to tumor progression. The identification of an HLA-A1-restricted peptide derived from S100A4 will allow to investigate if active immunisation to $\mathrm{S} 100 \mathrm{~A}^{+}$cells is an feasible option for anti-cancer immunotherapy.

Acknowledgments This work was funded by the Deutsche Forschungsgemeinschaft/DFG (KFO 124).

Open Access This article is distributed under the terms of the Creative Commons Attribution Noncommercial License which permits any noncommercial use, distribution, and reproduction in any medium, provided the original author(s) and source are credited.

\section{References}

1. Agerbaek M, Alsner J, Marcussen N, Lundbeck F, Von der MH (2006) Focal S100A4 protein expression is an independent predictor of development of metastatic disease in cystectomized bladder cancer patients. Eur Urol 50:777-785

2. Ai KX, Lu LY, Huang XY, Chen W, Zhang HZ (2008) Prognostic significance of S100A4 and vascular endothelial growth factor expression in pancreatic cancer. World J Gastroenterol 14:19311935

3. Andersen K, Nesland JM, Holm R, Florenes VA, Fodstad O, Maelandsmo GM (2004) Expression of S100A4 combined with reduced E-cadherin expression predicts patient outcome in malignant melanoma. Mod Pathol 17:990-997

4. Basile DP, Fredrich K, Alausa M, Vio CP, Liang M, Rieder MR, Greene AS, Cowley AW Jr (2005) Identification of persistently altered gene expression in the kidney after functional recovery from ischemic acute renal failure. Am J Physiol Renal Physiol 288:F953-F963 
5. Berke Z, Andersen MH, Pedersen M, Fugger L, Zeuthen J, Haurum JS (2000) Peptides spanning the junctional region of both the $\mathrm{abl} / \mathrm{bcr}$ and the bcr/abl fusion proteins bind common HLA class I molecules. Leukemia 14:419-426

6. Brisset AC, Hao H, Camenzind E, Bacchetta M, Geinoz A, Sanchez JC, Chaponnier C, Gabbiani G, Bochaton-Piallat ML (2007) Intimal smooth muscle cells of porcine and human coronary artery express S100A4, a marker of the rhomboid phenotype in vitro. Circ Res 100:1055-1062

7. Brocker EB, Kuhlencordt KM, Muller-Ruchholtz W (1977) Microcytotoxicity test in allograft immunity: specificity and kinetics of effector T cells. Int Arch Allergy Appl Immunol 53:234-241

8. Cabezon T, Celis JE, Skibshoj I, Klingelhofer J, Grigorian M, Gromov P, Rank F, Myklebust JH, Maelandsmo GM, Lukanidin E, Ambartsumian N (2007) Expression of S100A4 by a variety of cell types present in the tumor microenvironment of human breast cancer. Int J Cancer 121:1433-1444

9. Chang HJ, Yoo BC, Kim SW, Lee BL, Kim WH (2007) Significance of PML and p53 protein as molecular prognostic markers of gallbladder carcinomas. Pathol Oncol Res 13:326-335

10. Cho YG, Kim CJ, Nam SW, Yoon SH, Lee SH, Yoo NJ, Lee JY, Park WS (2005) Overexpression of S100A4 is closely associated with progression of colorectal cancer. World J Gastroenterol 11:4852-4856

11. Davies BR, O’Donnell M, Durkan GC, Rudland PS, Barraclough R, Neal DE, Mellon JK (2002) Expression of S100A4 protein is associated with metastasis and reduced survival in human bladder cancer. J Pathol 196:292-299

12. de Silva RS, Martin L, Roshanlall C, Winstanley J, Leinster S, Platt-Higgins A, Carroll J, West C, Barraclough R, Rudland P (2006) Association of S100A4 and osteopontin with specific prognostic factors and survival of patients with minimally invasive breast cancer. Clin Cancer Res 12:1192-1200

13. DiBrino M, Tsuchida T, Turner RV, Parker KC, Coligan JE, Biddison WE (1993) HLA-A1 and HLA-A3 T cell epitopes derived from influenza virus proteins predicted from peptide binding motifs. J Immunol 151:5930-5935

14. Ganesan K, Ivanova T, Wu Y, Rajasegaran V, Wu J, Lee MH, Yu K, Rha SY, Chung HC, Ylstra B, Meijer G, Lian KO, Grabsch H, Tan P (2008) Inhibition of gastric cancer invasion and metastasis by PLA2G2A, a novel beta-catenin/TCF target gene. Cancer Res 68:4277-4286

15. Garrett SC, Varney KM, Weber DJ, Bresnick AR (2006) S100A4, a mediator of metastasis. J Biol Chem 281:677-680

16. Grigorian M, Tulchinsky E, Burrone O, Tarabykina S, Georgiev G, Lukanidin E (1994) Modulation of mts1 expression in mouse and human normal and tumor cells. Electrophoresis 15:463-468

17. Gupta S, Hussain T, MacLennan GT, Fu P, Patel J, Mukhtar H (2003) Differential expression of S100A2 and S100A4 during progression of human prostate adenocarcinoma. J Clin Oncol 21:106112

18. Helfman DM, Kim EJ, Lukanidin E, Grigorian M (2005) The metastasis associated protein S100A4: role in tumour progression and metastasis. Br J Cancer 92:1955-1958

19. Hemandas AK, Salto-Tellez M, Maricar SH, Leong AF, Leow CK (2006) Metastasis-associated protein S100A4-a potential prognostic marker for colorectal cancer. J Surg Oncol 93:498-503

20. Hofmeister V, Schrama D, Becker JC (2008) Anti-cancer therapies targeting the tumor stroma. Cancer Immunol Immunother 57:1-17

21. Hofmeister V, Vetter C, Schrama D, Brocker EB, Becker JC (2006) Tumor stroma-associated antigens for anti-cancer immunotherapy. Cancer Immunol Immunother 55:481-494

22. Ismail NI, Kaur G, Hashim H, Hassan MS (2008) S100A4 overexpression proves to be independent marker for breast cancer progression. Cancer Cell Int 8:12. doi:10.1186/1475-2867-8-12
23. Ito $\mathrm{Y}$, Yoshida H, Tomoda C, Uruno T, Miya A, Kobayashi K, Matsuzuka F, Kakudo K, Kuma K, Miyauchi A (2004) S100A4 expression is an early event of papillary carcinoma of the thyroid. Oncology 67:397-402

24. Ji L, Zhang WG, Liu J, Liu XP, Yao LB (2004) Construction and analysis of subtractive cDNA library associated with multidrug resistance of acute leukemia. Zhongguo Shi Yan Xue Ye Xue Za Zhi 12:431-435

25. Kikuchi N, Horiuchi A, Osada R, Imai T, Wang C, Chen X, Konishi I (2006) Nuclear expression of S100A4 is associated with aggressive behavior of epithelial ovarian carcinoma: an important autocrine/paracrine factor in tumor progression. Cancer Sci 97:1061-1069

26. Kim YJ, Kim MA, Im SA, Kim TM, Kim DW, Yang HK, Heo DS, Lee KU, Choe KJ, Kim NK, Kim TY, Kim WH, Bang YJ (2008) Metastasis-associated protein S100A4 and p53 predict relapse in curatively resected stage III and IV (M0) gastric cancer. Cancer Invest 26:152-158

27. Kimura K, Endo Y, Yonemura Y, Heizmann CW, Schafer BW, Watanabe Y, Sasaki T (2000) Clinical significance of S100A4 and E-cadherin-related adhesion molecules in non-small cell lung cancer. Int J Oncol 16:1125-1131

28. Kozlova EN, Lukanidin E (1999) Metastasis-associated mts 1 (S100A4) protein is selectively expressed in white matter astrocytes and is up-regulated after peripheral nerve or dorsal root injury. Glia 27:249-258

29. Kozlova EN, Lukanidin E (2002) Mts1 protein expression in the central nervous system after injury. Glia 37:337-348

30. Lee WY, Su WC, Lin PW, Guo HR, Chang TW, Chen HH (2004) Expression of S100A4 and Met: potential predictors for metastasis and survival in early-stage breast cancer. Oncology 66:429-438

31. Li H, Fan X, Houghton J (2007) Tumor microenvironment: the role of the tumor stroma in cancer. J Cell Biochem 101:805-815

32. Maelandsmo GM, Florenes VA, Mellingsaeter T, Hovig E, Kerbel RS, Fodstad O (1997) Differential expression patterns of S100A2, S100A4 and S100A6 during progression of human malignant melanoma. Int J Cancer 74:464-469

33. Maelandsmo GM, Hovig E, Skrede M, Engebraaten O, Florenes VA, Myklebost O, Grigorian M, Lukanidin E, Scanlon KJ, Fodstad O (1996) Reversal of the in vivo metastatic phenotype of human tumor cells by an anti-CAPL (mts1) ribozyme. Cancer Res 56:5490-5498

34. Matsubara D, Niki T, Ishikawa S, Goto A, Ohara E, Yokomizo T, Heizmann CW, Aburatani H, Moriyama S, Moriyama H, Nishimura Y, Funata N, Fukayama M (2005) Differential expression of S100A2 and S100A4 in lung adenocarcinomas: clinicopathological significance, relationship to p53 and identification of their target genes. Cancer Sci 96:844-857

35. Middleton D, Menchaca L, Rood H, Komerofsky R (2003) New allele frequency database: http://www.allelefrequencies.net. Tissue Antigens 61:403-407

36. Min HS, Choe G, Kim SW, Park YJ, Park DJ, Youn YK, Park SH, Cho BY, Park SY (2008) S100A4 expression is associated with lymph node metastasis in papillary microcarcinoma of the thyroid. Mod Pathol 21:748-755

37. Nikitenko LL, Lloyd BH, Rudland PS, Fear S, Barraclough R (2000) Localisation by in situ hybridisation of S100A4 (p9Ka) mRNA in primary human breast tumour specimens. Int $\mathrm{J}$ Cancer 86:219-228

38. Ninomiya I, Ohta T, Fushida S, Endo Y, Hashimoto T, Yagi M, Fujimura T, Nishimura G, Tani T, Shimizu K, Yonemura Y, Heizmann CW, Schafer BW, Sasaki T, Miwa K (2001) Increased expression of S100A4 and its prognostic significance in esophageal squamous cell carcinoma. Int J Oncol 18:715-720

39. Nonaka D, Chiriboga L, Rubin BP (2008) Differential expression of $\mathrm{S} 100$ protein subtypes in malignant melanoma, and benign and 
malignant peripheral nerve sheath tumors. J Cutan Pathol 35:1014-1019

40. Oida Y, Yamazaki H, Tobita K, Mukai M, Ohtani Y, Miyazaki N, Abe Y, Imaizumi T, Makuuchi H, Ueyama Y, Nakamura M (2006) Increased S100A4 expression combined with decreased E-cadherin expression predicts a poor outcome of patients with pancreatic cancer. Oncol Rep 16:457-463

41. Oslejskova L, Grigorian M, Gay S, Neidhart M, Senolt L (2008) The metastasis associated protein S100A4: a potential novel link to inflammation and consequent aggressive behavior of rheumatoid arthritis synovial fibroblasts. Ann Rheum Dis 67:1499-1504

42. Parker KC, Bednarek MA, Coligan JE (1994) Scheme for ranking potential HLA-A2 binding peptides based on independent binding of individual peptide side-chains. J Immunol 152:163-175

43. Rammensee H, Bachmann J, Emmerich NP, Bachor OA, Stevanovic S (1999) SYFPEITHI: database for MHC ligands and peptide motifs. Immunogenetics 50:213-219

44. Rand V, Prebble E, Ridley L, Howard M, Wei W, Brundler MA, Fee BE, Riggins GJ, Coyle B, Grundy RG (2008) Investigation of chromosome 1q reveals differential expression of members of the S100 family in clinical subgroups of intracranial paediatric ependymoma. Br J Cancer 99:1136-1143

45. Rosty C, Ueki T, Argani P, Jansen M, Yeo CJ, Cameron JL, Hruban RH, Goggins M (2002) Overexpression of S100A4 in pancreatic ductal adenocarcinomas is associated with poor differentiation and DNA hypomethylation. Am J Pathol 160:45-50

46. Rudland PS, Platt-Higgins A, Renshaw C, West CR, Winstanley JH, Robertson L, Barraclough R (2000) Prognostic significance of the metastasis-inducing protein S100A4 (p9Ka) in human breast cancer. Cancer Res 60:1595-1603

47. Santamaria-Kisiel L, Rintala-Dempsey AC, Shaw GS (2006) Calcium-dependent and -independent interactions of the $\mathrm{S} 100$ protein family. Biochem J 396:201-214

48. Schmidt-Hansen B, Klingelhofer J, Grum-Schwensen B, Christensen A, Andresen S, Kruse C, Hansen T, Ambartsumian N, Lukanidin E, Grigorian M (2004) Functional significance of metastasis-inducing S100A4 (Mts1) in tumor-stroma interplay. J Biol Chem 279:24498-24504
49. Schneider M, Hansen JL, Sheikh SP (2008) S100A4: a common mediator of epithelial-mesenchymal transition, fibrosis and regeneration in diseases? J Mol Med 86:507-522

50. Schneider M, Kostin S, Strom CC, Aplin M, Lyngbaek S, Theilade J, Grigorian M, Andersen CB, Lukanidin E, Lerche HJ, Sheikh SP (2007) S100A4 is upregulated in injured myocardium and promotes growth and survival of cardiac myocytes. Cardiovasc Res 75:40-50

51. Shi Y, Zou M, Collison K, Baitei EY, Al Makhalafi Z, Farid NR, Al Mohanna FA (2006) Ribonucleic acid interference targeting S100A4 (Mts1) suppresses tumor growth and metastasis of anaplastic thyroid carcinoma in a mouse model. J Clin Endocrinol Metab 91:2373-2379

52. Takenaga K, Nygren J, Zelenina M, Ohira M, Iuchi T, Lukanidin E, Sjoquist M, Kozlova EN (2007) Modified expression of Mts1/ S100A4 protein in C6 glioma cells or surrounding astrocytes affects migration of tumor cells in vitro and in vivo. Neurobiol Dis 25:455-463

53. Taylor S, Herrington S, Prime W, Rudland PS, Barraclough R (2002) S100A4 (p9Ka) protein in colon carcinoma and liver metastases: association with carcinoma cells and T-lymphocytes. Br J Cancer 86:409-416

54. Wang G, Platt-Higgins A, Carroll J, de Silva RS, Winstanley J, Barraclough R, Rudland PS (2006) Induction of metastasis by $\mathrm{S} 100 \mathrm{P}$ in a rat mammary model and its association with poor survival of breast cancer patients. Cancer Res 66:1199-1207

55. Yonemura Y, Endou Y, Kimura K, Fushida S, Bandou E, Taniguchi K, Kinoshita K, Ninomiya I, Sugiyama K, Heizmann CW, Schafer BW, Sasaki T (2000) Inverse expression of S100A4 and E-cadherin is associated with metastatic potential in gastric cancer. Clin Cancer Res 6:4234-4242

56. Zhang B, Bowerman NA, Salama JK, Schmidt H, Spiotto MT, Schietinger A, Yu P, Fu YX, Weichselbaum RR, Rowley DA, Kranz DM, Schreiber H (2007) Induced sensitization of tumor stroma leads to eradication of established cancer by T cells. J Exp Med 204:49-55

57. Zou M, Al Baradie RS, Al Hindi H, Farid NR, Shi Y (2005) S100A4 (Mts1) gene overexpression is associated with invasion and metastasis of papillary thyroid carcinoma. Br J Cancer 93:1277-1284 